\title{
MINIMIZATION OF NO EMISSIONS FROM MULTI-BURNER COAL-FIRED BOILERS
}

\author{
E.G. Eddings, A. Molina, D. W. Pershing, A. F. Sarofim \\ Dept. of Chemical and Fuels Engineering, University of Utah \\ K. A. Davis and M. P. Heap \\ Reaction Engineering International \\ T. H. Fletcher, H. Zhang \\ Dept. of Chemical Engineering, Brigham Young University
}

Department of Energy

University Coal Research Program

SEMI-ANNUAL REPORT

Grant No. DE-FG26-97FT97275--02

March 1998
through
August 1998 


\section{Program Overview}

The focus of this program is to provide insight into the formation and minimization of NOx in multi-burner arrays, such as those that would be found in a typical utility boiler. Most detailed studies are performed in single-burner test facilities, and may not capture significant burner-toburner interactions that could influence NOx emissions.

Our approach is to investigate such interactions by a combination of single and multiple burner experiments in a pilot-scale coal-fired test facility at the University of Utah, and by the use of computational combustion simulations to provide insight into the experimental results and to evaluate full-scale utility boilers. In addition, fundamental studies on nitrogen release from coal will be performed in support of the modeling effort. Improved submodels describing transformations of both volatile nitrogen species and char nitrogen species will be developed.

The program is broken into four main tasks, and reporting will be divided into these main areas:

1- Fundamental studies on nitrogen release from coal. These studies will be used to enhance the predictive capabilities of the combustion simulations. Studies focusing on secondary coal pyrolysis will be carried out at Brigham Young University, and studies focusing on char nitrogen will be performed at the University of Utah.

2- Comprehensive modeling of burner arrays. This task will be performed by Reaction Engineering International and the Unversity of Utah.

3- Pilot-scale optimization of multi-burner arrays. This task will be carried out by the University of Utah.

4- Technology transfer. This task involves coordination with utility consultants who will provide oversight of the research program. 


\section{FUNDAMENTAL STUDIES ON NITROGEN RELEASE FROM COAL}

\section{Nitrogen Transformations during Secondary Coal Pyrolysis}

\section{Introduction}

Coal contines to be one of the principal energy sources for electric power generation in the United States. One of the biggest environmental challenges involved with coal utilization is the reduction of nitrogen oxides $\left(\mathrm{NO}_{\mathrm{x}}\right)$ formed during coal combustion. The most economical method of $\mathrm{NO}_{\mathrm{x}}$ abatement in coal combustion is through burner modification. Air-staging techniques have been widely used in the development of low- $\mathrm{NO}_{\mathrm{x}}$ pulverized coal burners, promoting the conversion of $\mathrm{NO}_{\mathrm{x}}$ to $\mathrm{N}_{2}$ by delaying the mixing in the fuel-rich zone near the burner inlet. Previous studies have looked at the mechanisms of $\mathrm{NO}_{\mathrm{x}}$ evolution at relatively low temperatures where primary pyrolysis is dominant, but data published for secondary pyrolysis in the pulverized coal furnace are scarce. In this project, the nitrogen evolution behavior during secondary coal pyrolysis will be explored. The end result will be a complete model of nitrogen evolution and $\mathrm{NO}_{\mathrm{x}}$ precursor formation due to primary and secondary pyrolysis.

\section{Project Objective}

At high heating rates $\left(>10^{4} \mathrm{~K} / \mathrm{s}\right)$, primary coal pyrolysis begins at temperatures of 900 to $1000 \mathrm{~K}$. Secondary pyrolysis is defined as the pyrolysis of volatile products that have already been released from the coal particles, and occurs at temperatures greater than $1100 \mathrm{~K}$. At these higher temperatures, a small amount of additional nitrogen is also released as primary products from the char, generally in the form of $\mathrm{HCN}$. Primary pyrolysis has been studied extensively, while less is known about secondary pyrolysis. Secondary pyrolysis can become more important in the fuel-rich regions created by air staging (both in low-NOx burners and in less localized staging concepts such as overfire air).

The goal of this project is to study the nitrogen transformations during secondary coal pyrolysis which occurs after primary devolatilization but before significant volatile combustion and char oxidation occur. The partitioning of nitrogen in the gas phase, char and soot will be 
measured. Special emphasis will be placed on the formation and evolution of $\mathrm{NO}_{\mathrm{x}}$ precursors such as $\mathrm{HCN}$ and $\mathrm{NH}_{3}$. A model of secondary pyrolysis including tar reduction, soot formation, and nitrogen transformation will be developed in conjunction with the Chemical Percolation Devolatilization (CPD) model [1] to predict $\mathrm{NO}_{\mathrm{x}}$ formation during pulverized coal pyrolysis.

\section{Approach}

The major portion of the experimental work will be conducted in a flat-flame burner (FFB) operated in fuel-rich mode. This experiment provides a high temperature laminar flow reactor environment with no $\mathrm{O}_{2}$ present in order to conduct secondary pyrolysis experiments. However, since minimum flame temperatures in the FFB are about $1600 \mathrm{~K}$, several additional tests will be also made in a drop-tube reactor to provide data at lower temperatures.

\section{Accomplishments}

Initial concentration measurements of $\mathrm{HCN}$ and $\mathrm{NH}_{3}$ were performed in the $\mathrm{FFB}$ for both Illinois \#6 and Utah coals using a 5-m gas cell attached to a Bomem FTIR. Concentrations of these species were found to decrease significantly after initially being formed. Computations of the gas species in the post-flame gases of a fuel-rich $\mathrm{CH}_{4} / \mathrm{H}_{2} / \mathrm{O}_{2} / \mathrm{N}_{2}$ flame, doped with $\mathrm{HCN}$ and/or $\mathrm{NH}_{3}$, were performed using CHEMKIN-II and the GRI 2.11 mechanism. CHEMKINII calculations show that nitrogen precursors are sustained better in the post flame of a $\mathrm{CH}_{4}$ flame than in a CO flame. This must be accounted for in the measurements and resultant modeling.

Coal pyrolysis experiments were conducted on two coals, namely an Illinois \#6 and a Utah bituminous coal. The coals were pulverized and sieved to obtain the $45-75 \mu \mathrm{m}$ fraction, and then dried at $105^{\circ} \mathrm{C}$ for two hours before injection into the flat-flame burner (FFB). The ultimate and proximate analyses of the two coals are shown in Table 1. Ultimate analysis was performed on a LECO 932 CHNS elemental analyzer using coal sample sizes of approximately $1.5 \mathrm{mg}$. 
Table 1. Ultimate and Proximate Analysis of Coals Used

\begin{tabular}{|l|l|l|l|l|l|l|l|l|}
\hline Coal & \multicolumn{2}{|l|}{ Proximate analysis (wt\%,db) } & \multicolumn{4}{l|}{ Ultimate analysis (wt\%,daf) } \\
\hline & ash & $\begin{array}{l}\text { volatile } \\
\text { matter }\end{array}$ & fixed carbon & C & H & N & $\mathrm{O}^{\dagger}$ & S \\
\hline Illinois \#6 & 12.435 & 42.695 & 44.870 & 76.004 & 5.476 & 1.523 & 12.317 & 4.680 \\
\hline Utah & 9.817 & 44.495 & 45.688 & 81.436 & 5.873 & 1.639 & 10.500 & 0.533 \\
\hline
\end{tabular}

$\mathrm{O}=100-(\mathrm{C}+\mathrm{H}+\mathrm{N}+\mathrm{S})$

Experiments were performed for one temperature condition in the FFB using a $\mathrm{CO}$ flame, sampling at various residence times. The equivalence ratio was adjusted to be approximately 1.20 in order to create a fuel-rich environment in the post-flame region. The flows of fuels and oxidizers used to generate this temperature condition are shown in Table 2. The temperatures were measured using a type-B thermocouple (OMEGA Engineering) and corrected for radiation loss.

Table 2. CO Flame Conditions

\begin{tabular}{|l|l|l|l|l|l|l|l|}
\hline $\begin{array}{l}\text { peak } \\
\text { temperature }\end{array}$ & $\begin{array}{l}\text { Air } \\
(\mathrm{slpm} *)\end{array}$ & $\begin{array}{l}\mathrm{CO} \\
(\mathrm{slpm})\end{array}$ & $\begin{array}{l}\mathrm{H}_{2} \\
(\mathrm{slpm})\end{array}$ & $\begin{array}{l}\text { Dilution } \mathrm{N}_{2} \\
(\mathrm{slpm})\end{array}$ & $\begin{array}{l}\text { Carrier } \mathrm{N}_{2} \\
(\mathrm{slpm})\end{array}$ & $\begin{array}{l}\text { Quench } \\
\mathrm{N}_{2}(\mathrm{slpm})\end{array}$ & $\begin{array}{l}\text { Equivalenc } \\
\text { ratio }\end{array}$ \\
\hline $\begin{array}{l}1640 \mathrm{~K} \\
(\text { condition } 1)\end{array}$ & 19.5 & 12 & 0.35 & 10.2 & 0.0365 & 60 & 1.2058 \\
\hline
\end{tabular}

* slpm: standard litter per minute

Mass release of coal was determined using an Inductively Coupled Plasma (ICP) method to determine mineral tracers, since measurement from directly weighing the mass of coal and char is not sufficiently accurate. A nitrogen balance was performed from the elemental analyses of the char and soot; gas phase elemental composition in these figures is by difference. The nitrogen distributions for the Illinois and Utah pyrolysis experiments in $1640 \mathrm{~K} \mathrm{CO}$ flame 
are presented in Figures 1 and Figure 2 respectively. These data show that the nitrogen in the soot initially increases with residence time for both coals, although the soot nitrogen begins to drop at long residence times for the Utah coal. The nitrogen in the gas phase demonstrates the same trend: an initial decrease of nitrogen in the gas followed by a steady increase. Nitrogen retained in the char decreases monotonically for the Utah coal; while for Illinois coal, char nitrogen increases at early residence times but drops at longer residence times.

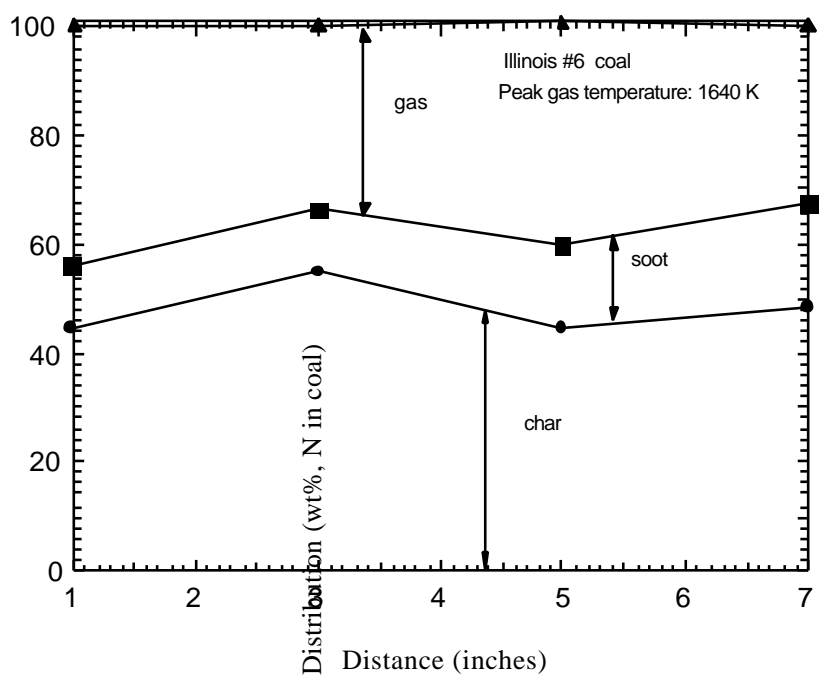

Figure 1. Cumulative nitrogen distribution for the Illinois \#6 coal pyrolysis experiments in the $1640 \mathrm{~K} \mathrm{CO}$ flame (condition 1). 


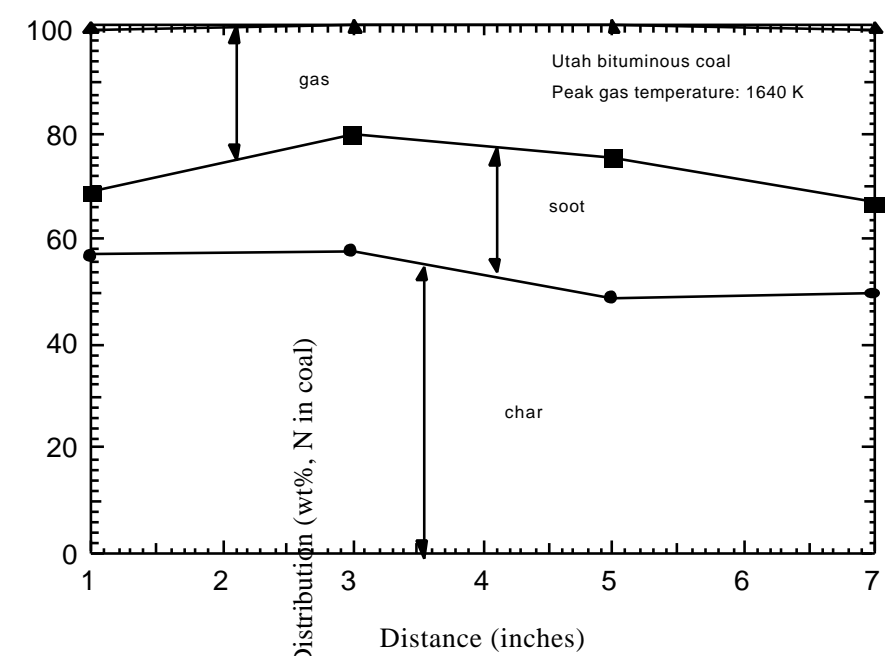

Figure 2. Cumulative nitrogen distribution for the Utah coal pyrolysis experiments in the 1640 K CO flame (condition 1).

\section{Future Work}

Plans include testing additional coals with a wider range of rank from lignite to lvb bituminous. Three additional higher temperature conditions will be also tested for all the coals. Some supplementary experiments in HPCP will provide additional data for model development.

\section{References}

1. Fletcher, T. H., A. R. Kerstein, R. J. Pugmire, M. S. Solum, and D. M. Grant, "A Chemical Model of Coal Devolatilization: 3. Direct Use of ${ }^{13}$ C NMR Data to Predict Effects of Coal Type," Energy and Fuels, 6(4), 414-431 (1992). 


\section{Char Nitrogen Studies: Transfer of the MIT Oxidation Drop Tube Furnace to the University of Utah}

During this period the work was focused on setting up an oxidation Drop Tube transferred from the MIT to the University of Utah. A brief description on the importance of the Drop Tube as research facility, as well as of some adjustments required during its installation at the university of Utah is presented.

\section{INTRODUCTION}

The oxidation Drop Tube is a laminar, entrained flow reactor that allows conducting tests at high temperature (up to $1750 \mathrm{~K}$ ) under a wide range of atmospheres, ranging from inert to pure oxygen. The energy is provided by an Astro model 1000A-3560 graphite element furnace. Its design is optimum for the study of the kinetic of reactions occurring during short periods of time (up to one second), but can also be used for longer times by suspending the particles in the heating zone using a crucible.

The furnace has been used for studying a range of problems including ultra fine particle formation, ash transformations, coal devolatilization, char oxidation, flash smelting, NO-char reactions, $\mathrm{SO}_{3}$ formation and $\mathrm{SO}_{2}$ capture. Some of these studies lead to the following publications:

- Pohl, J. and Sarofim, A. Sixteenth Symposium (International) on Combustion/ The Combustion Institute 1976, 491

- Neville, M., Quann, R.J., Haynes, B.S., Sarofim, A.F. Vaporization and condensation of Mineral Matter During Pulverized Coal Combustion. Eighteenth Symposium (International) on Combustion/The Combustion Institute 1980, 1267

- Levy, J., Chan, A., Sarofim, A., and Beér, J. Eighteenth Symposium (International) on Combustion/The Combustion Institute 1981, 111

- Song, Y., Beér, J. and Sarofim, A. Combust. Sci. and Tech. 1982, 28, 177 
- Song, Y., Beér, J. and Sarofim, A. Combustion Science and Technology 1981, 25, 237

- Song, Y., Pohl, J., Beer, J. and Sarofim, A. Combust. Sci. and Tech. 1982, 28, 31

- Chan, L., Sarofim, A. and Béer, J. Combustion and Flame 1983, 52, 37

- Torres-Ordonex, R.J., Longwell, J.P. and Sarofim, A.F. Physical Transformations during $\mathrm{CaS}$ (s) oxidation. Energy and Fuels 1989, 595

- Helbe, J.J. and Sarofim, A.F. Influence of char fragmentation on ash particle size distribution. Combustion and Flame 1989, 183

- Wornat, M.J. and Sarofim, A.F. Char- and aerosol-associated polycyclic aromatic compounds from coal pyrolysis. Relationship between particle size and surface composition. Aerosol Science and Technology 1990, 832

- Graham, K. and Sarofim, A.F. Inorganic Aerosol and their role in catalyzing sulfuric acid production in Furnaces. Journal of the Air \& Waste Management Association 1997, 48, 106

\section{OXIDATION DROP TUBE AT THE UNIVERSITY OF UTAH}

Considering the importance of a drop tube as an effective research tool for studying reactions at high temperature, one of these units that was previously at the Massachusetts Institute of Technology was transferred to the Combustion Research Laboratory at the University of Utah. The transferring process involved the design and construction of a semi-closed cooling system as well as the reconstruction of the gas and particle feeding system and gas/particle collecting facilities. Figure 1 presents a layout of the Drop Tube Unit including particle injection and collection systems. 


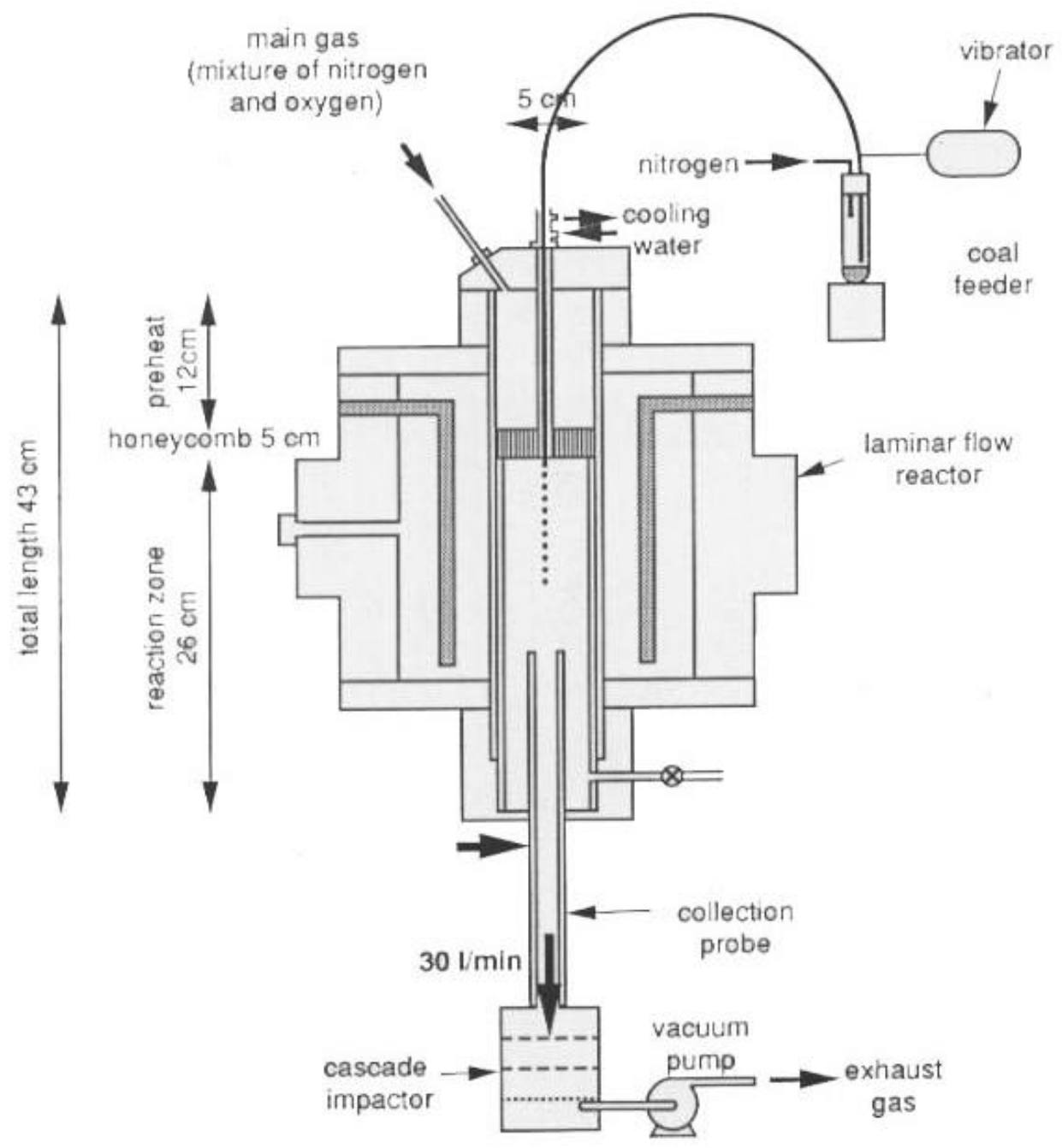

Figure 1. Schematics of the Oxidation Drop Tube Furnace 